7. Brown, L. R. et al. J. molec. Biol. 231, 800-816 (1993).

8. Katti, S. K., LeMaster, D. M. \& Eklund, H. J. molec. Biol. 212, 167-184 (1990).

9. Tomb, J.-F. Proc, natn. Acad. Sci. U.S.A. 89, 10252-10256 (1992).

11. Eklund, H. et al. J. molec. Biol. 228, 596-618 (1992).

12. Sodano, P. et al. J. molec. Biol. 221, 1311-1324 (1991).

13. Xia, T.-H. et al. Prot. Sci. 1, 310-321 (1992).

14. Epp, O., Ladenstein, R. \& Wendel, A. Eur. J. Biochem. 133, 51-69 (1983).

15. Reinemer, P. et al. EMBO J. 10, 1997-2005 (1991).

16. Ji, X., Zhang. P., Armstrong, R. N. \& Gilliland, G. L. Biochemistry 31, 10169-10184 (1992)

17. Thornton, J. M. J. molec. Biol. 151, 261-287 (1981).

18. Bardwell, J. C. A. et al. Proc. natn. Acad. Sci. U.S.A. 90, 11038-1042 (1993).

19. Dailey, F. E. \& Berg, H. C. Proc. natn. Acad. Sci. U.S.A. 90, 1043-1047 (1993).

20. Zapun, A., Bardwell, J. C. A. \& Creighton, T. E. Biochemistry (in the press).

21. Wünderlich, M., Jaenicke, R. \& Glockshuber, R. J. molec. Biol. (in the press).

22. Wünderlich, M. \& Glockshuber, R. Prot. Sci. 2, 717-726 (1993).

23. Krause, G., Lundström, J., Lopez-Barea, J., Pueyo de La Cuesta, C. \& Holmgren, A. J. biol. Chem. 266, 9494-9500 (1991). 1097-1100 (1993).

25. Edman, J. C., Ellis, L., Blacher, R. W., Roth, R. R. \& Rutter, W. J. Nature 317, 267-270 (1985)

26. Wilson, K. S. Acta crystallogr. B34, 1599-1608 (1978).

27. Terwilliger, T. C. \& Eisenberg, D. Acta crystallogr. A39, 813-817 (1983).

28. Weis, W. l., Kahn, R. Fourme, R., Drickamer, K. \& Hendrickson, W. A. Science 254, 1608 1615 (1991).

29. Jones, T. A., Zou, J. Y., Cowan, S. W. \& Kjeldgaard, M. Acta. cystallogr. A47, 110-119 (1991).

30. Wang, B. C. Meth. Enzym. 115, 90-112 (1985)

32. Brünger, A. T. X-PLOR (Version 3.1) Manual (The Howard Hughes Medical Institute and Department of Molecular Biophysics and Biochemistry, Yale University, 260 Whitney Avenue, New Haven, CT 06511, 1992).

33. Bernstein, F. C et al J. molec. Biol 112, 535-542 (1977)

34. Nicholls, A., Sharp, K. A. \& Honig, B. Proteins Struct. Funct. Genet. 11, 281-296 (1991). 35. Hendrickson, W. A. Science 254, 51-58 (1991).

ACKNOWLEDGEMENTS. We thank W. A. Hendrickson and C. Ogata for time on synchrotron beamline $X 4 A$ which is funded by the Howard Hughes Medical Institute at the Brookhaven National Laboratory; D. Kominos and B. Guenther for help in MAD data collection; W.A.H., W. I. Weis and $M$. Newman who helped with MAD data processing; $R$. Glockshuber for communicatin unpublished work; $Z$ Otwinowski for the DENZO program; and T. E. Creighton, X.P. Kong. E. Rattigan J. L. Kim, K. L. Clark and S. K. Burley. J. Was funded by a Helen Hay Whitney Beckwith and P. Model for helping to start this project.
10. Ellis, L. B. M., Saurugger, P. \& Woodward, C. Biochemistry 31, 4882-4891 (1992).

24. Martin, J. L. Waksman, G., Bardwell, J. C. A., Beckwith, J. \& Kuriyan, J. J. molec. Biol. 230

31. Zhang, K. Y. J. \& Main, P. Acta crystallogr. A46, 41-46 (1990). Fellows ip. Supported in part by grants from the NIH to J. Beckwith and J.K. We thank

\section{Amplification of calcium- induced gene transcription by nitric oxide in neuronal cells}

\section{Natalia Peunova \& Grigori Enikolopov}

Nature 364, 450-453 (1993)

IN this letter an earlier version of Fig. $3 c$ was printed instead of the revised and expanded figure which is discussed in the text and described in the legend. The correct figure is shown here.

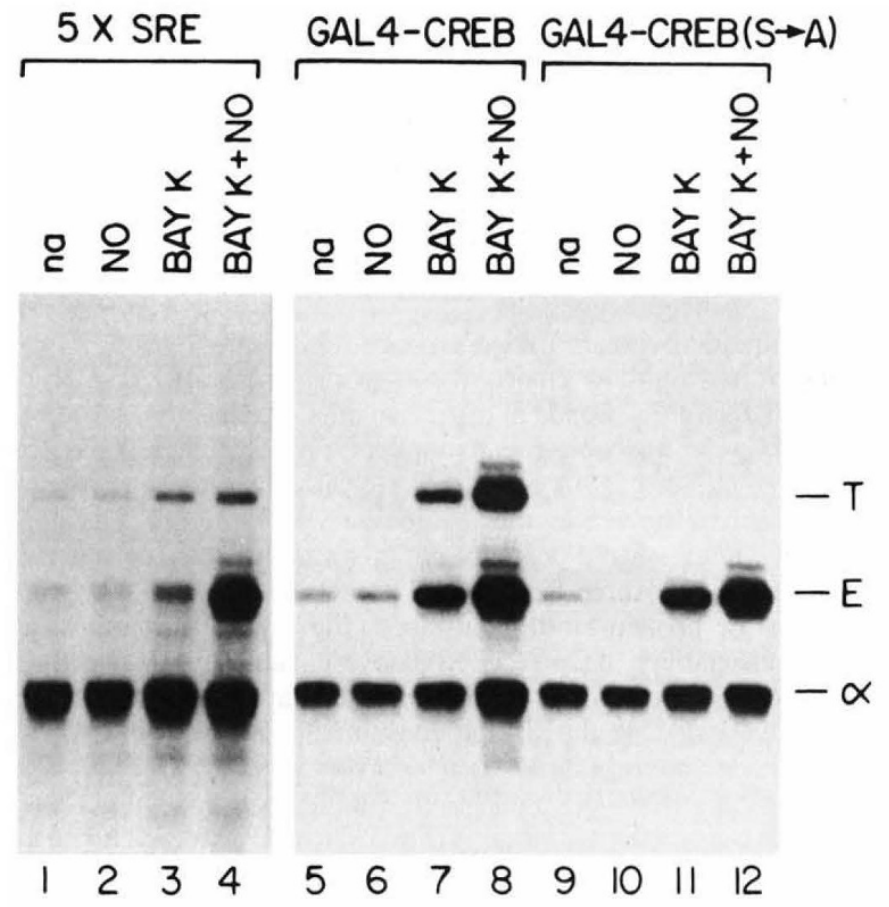

\section{CORRECTION}

\section{constrain coding exon junctional diversity in $\mathbf{V}(D) J$ recombination}

\section{Rachel M. Gerstein \& Michael R. Lieber}

Nature 363, 625-627 (1993)

DURING the production process, the key to Fig. 3 of this letter was inadvertently altered. The correct figure is shown.
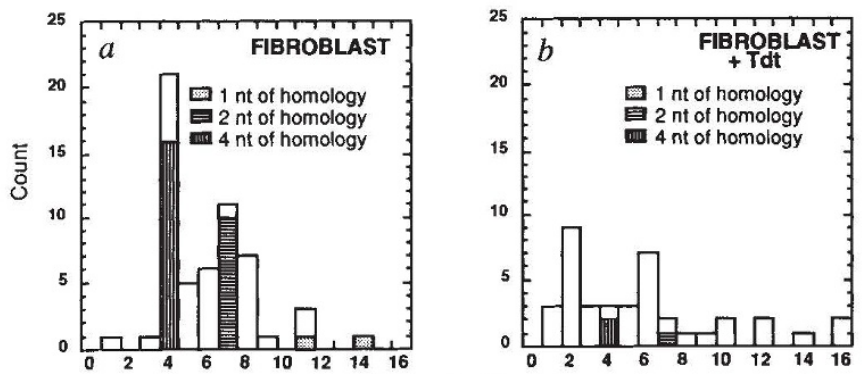

Total nucleotides lost

\section{A new component of the transcription factor DRTF1/E2F}

Rowena Girling, Janet F. Partridge, Lasantha R. Bandara, Neil Burden, Nicholas F. Totty, J. Justin Hsuan \& Nicholas B. La Thangue

Nature 362, 83-87 (1993)

THIs letter contains an error in the DP-1 cDNA sequence shown in Fig. $1 b$ which affects the codon reading frame from amino acid 388. The corrected sequence appears below, starting at position 1,217:

ACC CCI GTG TCC TAC GTT GGG GAG GAT GAT GAC GAC GAT GAT GAC ITT AAT GAG AAC GAC GAG GAG GAT $T P \vee S Y V G E D D D D D D D F N E N D E E D$

This correction does not alter any of the conclusions of the paper, although the open reading frame is now 410 amino acids. The corrected sequence has been submitted to the EMBL data base, accession number X72310. 